\title{
Simultaneous Determination of Epinephrine and Norepinephrine by High Performance Liquid Chromatography
}

\author{
Arun Mishra, Adesh UpadhyaY, \\ Arjun Patra, Sachin Chaudhury, Pronobesh Chattopadhyay *
}

Cellular and Microbiology Laboratory, College of Pharmacy, IFTM, Lodhipur Rajput - 243112, Moradabad 244001, Uttar Pradesh, India.

* Corresponding author. E-mail: chatto_pronobesh@rediffmail.com (P. Chattopadhyay)

Sci Pharm. 2009; 77: 367-374

doi:10.3797/scipharm.0902-07

Published: $\quad$ April $4^{\text {th }} 2009$

Accepted: $\quad$ April $2^{\text {nd }} 2009$

Received: $\quad$ February $15^{\text {th }} 2009$

This article is available from: http://dx.doi.org/10.3797/scipharm.0902-07

() Mishra et al.; licensee Österreichische Apotheker-Verlagsgesellschaft m. b. H., Vienna, Austria.

This is an Open Access article distributed under the terms of the Creative Commons Attribution License (http://creativecommons.org/licenses/by/3.0/), which permits unrestricted use, distribution, and reproduction in any medium, provided the original work is properly cited.

\begin{abstract}
Epinephrine and non-epinephrine are major endogenous catecholamines which are known as neurotransmitter. The plasma levels of catecholamines are significant markers of several neuro-endocrine disorders and autonomic nervous system disorders. A method for the simultaneous quantitation of epinephrine and norepinephrine is described. The related substances are resolved on a Phenomenex ODS analytical column C18 column $(150 \mathrm{~mm} \times 4.6 \mathrm{~mm}, 5 \mu \mathrm{m})$ using a mobile phase composed of a mixture of acetic acid and $50 \mathrm{mM}$ sodium acetate buffer $\mathrm{pH} 3.1(1: 99 \mathrm{v} / \mathrm{v})$ at a flow rate of $1 \mathrm{ml} / \mathrm{min}$ with UV detector at $285 \mathrm{~nm}$. The method is compatible with HPLC-MS and provides a tool for the control of substandard and counterfeit commercial preparations of epinephrine and norepinephrine.
\end{abstract}

\section{Keywords}

Adrenaline $\cdot$ Noraderaniline $\cdot$ HPLC

\section{Introduction}

The catecholamines are a group of compound bearing a dihydroxyphenyl moiety [1, 2]. The significances of the biogenic amines are employed as markers of neuroblastoma, stress condition and other autonomic nervous system disorders [3]. Catecholamines are also known as main neurotransmitters. Chemically, epinephrine (E) and norepinephrine 
(NE) are 4-[(1R)-1-hydroxy-2-(methylamino)ethyl]benzene-1,2-diol and 4-[(1R)-2-amino-1hydroxyethyl]benzene-1,2-diol, respectively. E was discovered as a hormone released from adrenal medulla. Later NE was established as a main neurotransmitter that is released from peripheral sympathetic nerves. The central neurotransmitter dopamine is known as a precursor of $\mathrm{E}$ and NE which plays an important role in the metabolism and regulation of sodium ions. Biogenic amines are low molecular weight intercellular messengers and act in chemical signaling $[4,5]$.<smiles>CNCC(O)c1ccc(O)c(O)c1</smiles>

a<smiles>NCC(O)c1ccc(O)c(O)c1</smiles>

b<smiles>NCCc1ccc(O)c(O)c1</smiles>

C

Fig. 1. Structures of biological amines: Epinephrine (a), Norepinephrine (b), Dopamine (c)

Previously catecholamines and small molecules were separated from plasma proteins by an internal-surface reversed-phase column (octadeyclsilica column) and were analyzed by liquid chromatography (LC)/mass spectrometry (MS) using electro spray ionization time-offlight MS [13], but by using HPLC and UV detector simultaneously analysis of NE and E methods are unavailable. HPLC methods are most reliable and most accurate methods as compared to other analytical techniques.

RIA [6, 7] and ELISA are two methods which are most commonly used for NE and E analysis. Previously HPLC with diode array detector [8] and HPLC with flurometric detector [9] were used but which are involved with multiple of step, complicated, time consuming procedure and sometimes non-reproducible results. Therefore the present study was designed to develop methodologie for the simultaneous estimation of catecholamines by RP-HPLC using C-18 column and UV detector.

\section{Materials and Methods}

\section{Materials}

Standard epinephrine and nor-epinephrine were obtained from Sigma-Aldrich (St Louis, MO, USA) and ammonium acetate was obtained from CDH Laboratory (Mumbai, India). Commercial preparations of $E$ and NE were obtained from Rathi Labs Hindustan (P) Ltd. Patna and Samarth Life Sciences (P) Ltd, Mumbai respectively. Methanol, acetic acid and water were used HPLC grade and purchased from Qualigens Fine Chemicals (Mumbai, India).

\section{Preparation of solutions}

\section{Standard solutions}

For HPLC analysis, $25 \mathrm{mg}$ of $\mathrm{E}$ and NE standards was accurately weighted by using a Citizen analytical balance (readability $0.01 \mathrm{mg}$ ). The weighted sample was made up to 
$25 \mathrm{ml}$ with HPLC grade water to produce a stock solution containing $1 \mu \mathrm{g} / \mathrm{ml} \mathrm{E}$ and NE respectively. Aliquots of the stock solution were suitably diluted with the mobile phase to produce calibration solutions of concentrations as described in the validation studies section.

\section{Sample preparation}

Samples (1 mg equivalent) of different commercial samples were pipetted out accurately, dissolved in and made up to $100 \mathrm{ml}$ with a solution in water. The obtained solution was diluted 10 -fold with the mobile phase prior to analysis.

\section{Ammonium acetate buffer ( $50 \mathrm{mM}, \mathrm{pH}$ 3.1)}

Ammonium acetate $(3.36 \mathrm{~g})$ was accurately weighted, dissolved in approximately $800 \mathrm{ml}$ of water and the $\mathrm{pH}$ adjusted to a value of 4.0 with acetic acid. The resulting solution was made up to $1 \mathrm{~L}$ with water.

\section{Validation studies}

The rectilinear relationship between concentrations of the analytes and the UV detector response were evaluated. The concentrations used were 10, 20, 30, 40, 50, 60, 70, 80, 90 and $100 \mathrm{ng} / \mathrm{mL}$ for NE and $\mathrm{E}$ respectively. Three different preparations of the analytical standard were analyzed in triplicate on the same day for the determination of intra-day assay precision. These determinations were repeated using freshly prepared standard solutions on three separate days to determine inter-day precision of analysis.

Analytical solutions and commercial sample in triplicate were freshly prepared solutions (as described in Section validation studies) at 3 separate days were used to compute the inter-day ( $n=3$ separate determinations) and intra-day precision of the method.

The stability of the analytical solutions was determined for $E$ and NE at the concentrations described above for the assessment of repeatability.

Analytical solutions were injected repeatedly $(n=36)$ over a $60 \mathrm{~h}$ period and R.S.D.s \% computed for the peak areas due to the respective analytes. The performance characteristics of the method were based on the resolution between the critical pair of $E$ and $\mathrm{NE}$ and the robustness of the method as a function small changes in the $\mathrm{pH}$ (between 3.1 and 3.5$)$, buffer strength ( 25 and $50 \mathrm{mM}$ sodium acetate) of the mobile phase, stability of analytical solutions and the effect of temperature $\left(20-40^{\circ} \mathrm{C}\right)$ on resolution. The limits of detection and quantitation for each analytes were determined as $\mathrm{S} / \mathrm{N}$ of three and R.S.D. $\% \leq 5 \%$, respectively.

\section{HPLC/HPLC-MS analysis}

An Agilent HP1100 series quaternary pump with ChemStation® software version 10.02 for data acquisition equipped with a HP1100 series UV-Vis detector were used. The HPLC was also coupled to an Agilent MSD SL single-quadrupole mass spectrometer via an electrospray ionisation source. $\mathrm{E}$ and NE were separated at ambient temperature on a Gemini C18 column (150 mm × $4.6 \mathrm{~mm}$ i.d., $5 \mu \mathrm{m}$ particle size, 110A ${ }^{\circ}$, Phenomenex, Cheshire, UK) coupled with a Phenomenex C18 Securigard $®$ column. The mobile phase composed of a mixture of acetic acid and 50mM ammonium acetate buffer $\mathrm{pH} 3.1$ (1:99 
$\mathrm{v} / \mathrm{v}$ ) was delivered at a flow rate of $1 \mathrm{ml} / \mathrm{min}$ with a split ratio of 1 in 50 . For mass spectrometric analysis, compounds were detected using the following conditions: nebulising gas pressure, $10 \mathrm{psi}$, drying gas flow rate, $7 \mathrm{l} / \mathrm{min}$; drying gas temperature, $300^{\circ} \mathrm{C}$; capillary voltage, $4000 \mathrm{~V}$; positive ion mode; gain: 1 ; threshold: 150 ; step size: 0.10 ; peak width:0.10 min; cycle time: $1.02 \mathrm{~s} /$ cycle. Data was acquired in full scan mode $(\mathrm{m} / \mathrm{z}$ $100-650)$ at a fragmentor voltage of $70 \mathrm{~V}$.

\section{Results}

The increasing of the ionic strength of ammonium acetate buffers resulted in an improvement in the chromatographic peak shapes. But at concentration of ammonium acetate buffer of 25 and $50 \mathrm{mM}$ the most sharp and prominent peaks were observed. This observation may be due to competition between the highly basic moieties of biological amines ( $E$ and $N E$ ) and the ammonium ions for electrostatic interaction with residual silanols. Optimal separation of the analytes was accessed by the resolution behavior between the critical pair of NE and E. Optimal separation was observed in ammonium acetate buffer at $50 \mathrm{mM}$ concentration and $\mathrm{pH} 3.1$ (Fig. 2). Further keeping view that instability of some silica-based columns at $\mathrm{pH}$ values of below 2.8, the method was further evaluated using ammonium acetate buffer at a $\mathrm{pH}$ of 3.1 .

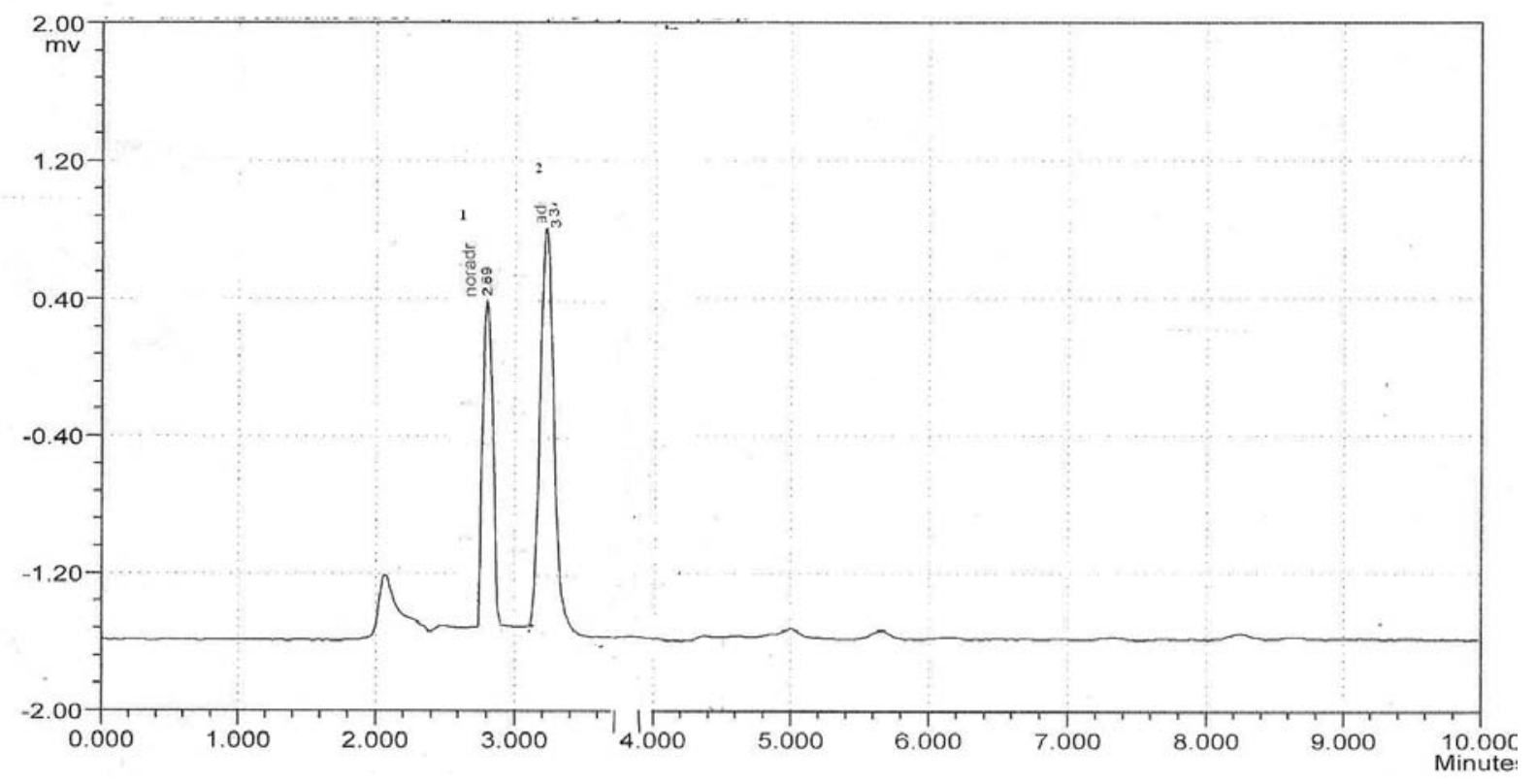

Fig. 2. Chromatogram of Norephinephrine and epinephrine simultaneously separated in same mobile phase. Peak of Norephinephrine marked as 1 and epinephrine marked as 2 respectively.

An assessment of the effect of temperature over a range of $20-40^{\circ} \mathrm{C}$ on the separation of the analytes showed a gradual, albeit insignificant with decrease in retention times with increasing of temperature which did not compromised resolution of the critical pair. Subsequently all analyses were performed at ambient temperature $\left(\approx 20^{\circ} \mathrm{C}\right)$. 
The stability of analytical solutions of E and NE assessed at three different concentrations which described in validation section and produced R.S.D. \% values $(n=36$ injections over $60 \mathrm{~h}$ ) of peak areas which were typically less than $2.5,1.3$ and $0.5 \%$ at low, intermediate and high concentrations respectively. Thus, solutions are sufficiently stable and enough to justify that analysis can be done after preparation of fresh samples over $24 \mathrm{~h}$ period.

The chromatographic peak areas showed a rectilinear relationship to analytes concentration within the specified ranges (Table 1) which are consistent with the expected concentrations on dilution of the innovator product Adrenaline (Rathi Laboratory Hindustan $(P)$ Ltd. Patna, India and Noradrenaline (Samarth Life Sciences (P) Ltd. Mumbai, India. Linear regression analysis showed that the correlation coefficients $\left(R^{2}\right)$ of all calibration curves were $\geq 0.994$ with minimal variation in the slopes and intercepts (Table 1).

The performance characteristics and validation data for the method using the mobile phase containing ammonium acetate buffer $(50 \mathrm{mM}, \mathrm{pH} 3.1)$ are summarized in Table 2. The intra-day assay precision (R.S.D. \%) of peak areas for $E$ and NE at the working concentration was $1 \mu \mathrm{g} / \mathrm{ml}(0.51)$ and $1 \mu \mathrm{g} / \mathrm{ml}(0.60)$ respectively.

Tab. 1. Regression analyses of calibration curves generated from the analysis of Epinephrine and Norephinephrine

\begin{tabular}{llllll}
\hline $\begin{array}{l}\text { Analyte } \\
\text { Correlation }\end{array}$ & $\begin{array}{l}\text { Range } \\
(\mathbf{n g} / \mathbf{m l})\end{array}$ & $\boldsymbol{n}$ & Slope & Intercept & Coefficient $\mathbf{( R}^{\mathbf{2}}$ ) \\
\hline Epinephrine & $20-60$ & 6 & $43.11 \pm 0.1$ & $57.80 \pm 4.2$ & $0.9997 \pm 0.0001$ \\
Norephinephrine & $20-80$ & 6 & $82.11 \pm 0.1$ & $19.23 \pm 3.7$ & $1.0000 \pm 0.0001$
\end{tabular}

The method was compatible with mass spectrometric detection and the compounds showed the following distinct signals in the spectra: $\mathrm{m} / \mathrm{z}=411$ and 217.2 for the $[\mathrm{M}]^{+}$and $[\mathrm{M}+\mathrm{H}]^{+}$ions due to $\mathrm{E}\left(\mathrm{t}_{\mathrm{R}}=4.7 \mathrm{~min}\right), \mathrm{NE}\left(\mathrm{t}_{\mathrm{R}}=3.6 \mathrm{~min}\right)$. The structural similarity of the related substances makes it difficult to distinguish between $E$ and NE based on MS data alone. The refinement of the MS data with chromatographic retention times enables unambiguous identification of these compounds.

\section{Discussion}

The challenges involved in the measurements of $E$ and NE in commercial preparation in accurately by conventional method. RIA and ELISA are established methods but simultaneously measurement of $E$ and NE is not established.

Catecholamines are readily oxidized and formed respective quinines. E and NE major related substances contain a highly basic amidino moiety which interacts with residual silanols on silica-based columns [10]. 
Tab. 2. Repeatability and sensitivity of HPLC method

\begin{tabular}{|c|c|c|}
\hline & Epinephrine & Norephinephrine \\
\hline \multicolumn{3}{|l|}{ Inter-day precision } \\
\hline Day $1(n=3)$ & $1 \mu \mathrm{g} / \mathrm{ml}, 4187 \pm 13.29,1.11 \%$ & $1 \mathrm{\mu g} / \mathrm{ml}, 2234 \pm 10.44,1.30 \%$ \\
\hline Day $2(n=3)$ & $2 \mu \mathrm{g} / \mathrm{ml}, 8210 \pm 16.55,1.55 \%$ & $2 \mu \mathrm{g} / \mathrm{ml}, 4052 \pm 12.20,1.62 \%$ \\
\hline Day $3(n=3)$ & $3 \mu \mathrm{g} / \mathrm{ml}, 12459 \pm 30.66,1.20 \%$ & $3 \mu \mathrm{g} / \mathrm{ml}, 6743 \pm 19.27,1.51 \%$ \\
\hline \multicolumn{3}{|l|}{ Intra-day precision } \\
\hline Solution $1(n=3)$ & $1 \mu \mathrm{g} / \mathrm{ml}, 4091 \pm 12.55,0.51 \%$ & $1 \mu \mathrm{g} / \mathrm{ml}, 2140 \pm 11.30,0.60 \%$ \\
\hline Solution $2(n=3)$ & $2 \mu \mathrm{g} / \mathrm{ml}, 8104 \pm 12.29,0.66 \%$ & $2 \mu \mathrm{g} / \mathrm{ml}, 3877 \pm 12.47,0.75 \%$ \\
\hline Solution $3(n=3)$ & $3 \mu \mathrm{g} / \mathrm{ml}, 12297 \pm 14.19,0.63 \%$ & $3 \mu \mathrm{g} / \mathrm{ml}, 6594 \pm 14.22,0.48 \%$ \\
\hline \multicolumn{3}{|l|}{ Limit of detection } \\
\hline $\mathrm{S} / \mathrm{N}(1 \mathrm{~mL})$ & 0.03 & 0.02 \\
\hline \multicolumn{3}{|l|}{$\begin{array}{l}\text { Limit of } \\
\text { quantitation }\end{array}$} \\
\hline R.S.D. $\% \leq 5(\mathrm{~g} / \mathrm{mL})$ & 0.07 & 0.06 \\
\hline \multicolumn{3}{|c|}{$\begin{array}{l}\text { All precision data are mean } \pm \text { S.D. }(n=3) \text { with R.S.D. \% values in parenthesis. Precision data represents } \\
\text { peak areas for analytes corrected for quantities of analytical standards materials used in the preparation } \\
\text { of solutions. The concentrations in } \mu \mathrm{g} / \mathrm{ml} \text { (italicized) represent the levels at which precision have been } \\
\text { assessed. }\end{array}$} \\
\hline
\end{tabular}

Gehrke et al [11] first time determined histamine, nor-epinephrine, octopamine, dopamine, serotonin and tyramine in urine by HPLC method by a pre-column derivatisation with o-phthalaldehyde. Though, after derivatisation molecules becomes stabilized for HPLC analysis but accuracy and sensitivity was questionable. Kumar et al [12] developed RPHPLC method for determine biological amines in biological fluid. However, till date the rapid and simple methods are unavailable. Therefore, the present investigation was important for analyzing biological amines in simply and rapidly.

Tab. 3. Precision of HPLC analysis of Epinephrine and Norephinephrine substances in a commercial sample

\begin{tabular}{lll}
\hline & Epinephrine & Norephinephrine \\
\hline Inter-day precision & & \\
Mean \pm S.D. $(n=3)(\% \mathrm{w} / \mathrm{w})$ & $71.02 \% \pm 0.46$ & $23.11 \pm 0.22$ \\
R.S.D. $\%$ & $0.59 \%$ & $0.40 \%$ \\
Intra-day precision & & \\
Mean \pm S.D. $(n=3)(\% \mathrm{w} / \mathrm{w})$ & $70.60 \% \pm 0.51$ & $22.60 \pm 0.47$ \\
R.S.D. $\%$ & $0.80 \%$ & $0.91 \%$
\end{tabular}


Tab. 4. Results from HPLC analysis of various commercial Epinephrine and Norephinephrine products

\begin{tabular}{|c|c|c|c|}
\hline & Volume of injection & Epinephrine & Norephinephrine \\
\hline Innovator specification & $3 \mathrm{ml}$ & $1 \mathrm{mg} / \mathrm{ml}$ & - \\
\hline Rathi Labs Hindustan (P) & & $940 \mu \mathrm{g} / \mathrm{ml}$ & - \\
\hline Ltd. Patna (1) & & & \\
\hline & $3 \mathrm{ml}$ & - & $1 \mathrm{mg} / \mathrm{ml}$ \\
\hline $\begin{array}{l}\text { Samarth Life Sciences } \\
\text { (P) Ltd. Mumbai (2) }\end{array}$ & & - & $960 \mu \mathrm{g} / \mathrm{ml}$ \\
\hline Mixed $1+2$ & $2 \mathrm{ml}$ & $\begin{array}{l}1 \mathrm{mg} / \mathrm{ml} \\
922 \mu \mathrm{g} / \mathrm{ml}\end{array}$ & $\begin{array}{l}1 \mathrm{mg} / \mathrm{ml} \\
957 \mu \mathrm{g} / \mathrm{ml}\end{array}$ \\
\hline
\end{tabular}

The present investigation shows that using of $\mathrm{NH}^{+}$containing mobile phases provides a competing ion to reduce analyte-silanol interactions.

The validation of the repeatability (inter- and intra-day precision) of the proposed HPLC method using the FDA approved product (Table 3) yielded R.S.D. \% values typically less than $2 \%$. It is obvious that the difficulties in its synthesis, the absence of regulatory standards and drug counterfeiting have resulted in the marketing of products

Recently developed LC/MS technique [13] for simultaneous determination of E and NE and their metabolites in plasma but the accuracy is questionable. HPLC methods are sensitive and more accurate compare with LC/MS and most manufacturers preferred the HPLC methods. Besides, LC-MS is an expensive technique and all manufacturers are not able to bear the cost of LC-MS. Therefore, the present investigation has importance for alternates of LC-MS analysis for E and NE.

\section{Acknowledgement}

The authors are thankful to Prof. A. K. Wahi, Dean, College of Pharmacy, IFTM for continuous support and encouragement. The authors are also thankful to Management, IFTM for providing Post Graduate Institutional Research Grant.

\section{Author's Statements}

\section{Competing Interests}

The authors declare no conflict of interest.

\section{References}

[1] Yildrim HK, Üren A, Yücel U.

Evaluation of biogenic amines in organic and non- organic wines by HPLC-OPA determination.

Food Technol Biotechnol. 2007; 45: 62-68.

[2] Tsunda M.

Recent advances in methods for the analysis of catecholamines and their metabolites.

Anal Bioanal Chem. 2006; 386: 506-514.

doi:10.1007/s00216-006-0675-z 
[3] Ball SG, Gunn IG, Doglus IH.

Renal handeling of Dopa, Dopamine, Noephnephrine, Ephinephrine in Dog.

Am J Physiol Renal Physiol. 1982; 242: F56-F62.

PMid:6800262

[4] Lake CR, Zigler MG, Kopin IJ.

Use of plasma norepinephrine for evaluation of sympathetic neuronal function in man.

Life Sci. 1976; 18: 1315-1326.

doi:10.1016/0024-3205(76)90210-1

[5] Shen XC, Gu CX, Qiu YQ, Du CJ, Fu YB, Wu JJ

Estrogen receptor expression in adrenocortical carcinoma.

Zhejiang Univ Sci B. 2009; 10: 1-6.

PMid:19198016

[6] Mefford N, Ivan, Ward MM, Miles L, Taylor B, Chesney M A, Keegan DL, Barchas JD.

Determination of plasma catecholamine and 3,4-dihydroxyphenylacetic acid in continuosly collected human plasma by high performance liquid chromatography with electrochemical detection.

Life Sci. 1981; 28: 477-483.

doi:10.1016/0024-3205(81)90140-5

[7] Cheng FC, Yang LL, Lin SK, Juang DJ, Chang WH, Kuo JS

Determination of human plasma biogenic amines and their metabolites using liquid chromatography with dual channel electrochemical detector.

Zhonghua Yi Xue Za Zhi (Taipei). 1995; 55: 15-24.

PMid:7536118

[8] Baid SK, Lai EW, Wesley RA, Ling A, Timmers HJ, Adams KT, Kozupa A, Pacak K.

Brief communication: radiographic contrast infusion and catecholamine release in patients with

pheochromocytoma.

Ann Intern Med. 2009; 150: 27-32.

PMid:19124817

[9] Tsunoda M.

[Role of Catecholamine metabolism in blood pressure regulation using chemiluminescence reaction detection.]

Yakugaku Zasshi. 2008; 128: 1589-1594.

doi:10.1248/yakushi.128.1589

[10] Alberto MR, Arena ME, Narda MC.

A comparative survey of two analytical methods for identification and quantification of biogenic amines.

Food Control. 2002; 13: 125-129.

doi:10.1016/S0956-7135(01)00051-2

[11] Gehrke CW, Davis TP, Cunningham TD, Kao KC, Gerhardt KO, Jhonson HD, Wilams CH.

High performance liquid chromatographic analysis of biogenic amines in biological amines as Ophtaldehyde derivatives.

J Chromatogr B. 1979; 162: 293-310.

doi:10.1016/S0378-4347(00)81516-9

[12] Qiu P, Chen X, Chen X, Lin L, Ai C.

Simultaneously determination of five alkaloids in body fluids by high performance liquid chromatography coupled with electro spray ionization tandem mass spectroscopy.

J Chromatogr B. 2008; 875: 471-477.

doi:10.1016/j.jchromb.2008.09.034

[13] Tomomi H, Kastuya W, Eiso H,Tsutomu M.

Pretreatment and one-shot separating analysis of whole catecholamine metabolites in plasma by using LC/MS.

Anal Bioanal Chem. 2006; 385: 814-820.

doi:10.1007/s00216-006-0459-5 